\title{
PUTUSAN SELA PERKARA PERDATA BILA PENGgUgat ASAL MENINGGAL DUNIA
}

\author{
I Kadek Agus Widiastika Adiputra, I Nyoman Gede Sugiartha, I Made Minggu Widyantara \\ Fakultas Hukum Universitas Warmadewa, Denpasar-Bali, Indonesia \\ aguswidiastika87@yahoo.com, nyomansugiartha14@gmail.com, mademinggu21@gmail.com
}

\begin{abstract}
Abstrak
Keputusan Majelis Hakim terhadap perkara perdata No. 414/Pdt.G/2019/PN Dps, yang tetap melanjutkan persidangan dan menetapkan putusan sela meskipun salah satu pihak penggugat telah meninggal dunia, bertentangan dengan Yurisprudensi Mahkamah Agung Republik Indonesia. Nomor 431K/Sip/1973, tanggal 9 Mei 1974. Penelitian ini bertujuan untuk menilai pengaturan putusan sela dalam hukum acara perdata dan menelaah pertimbangan hakim dalam menentukan proses persidangan dalam perkara putusan Nomor: 414/Pdt.G/2019/PN Dps saat penggugat asal meninggal dunia. Penelitian ini didesain dengan penelitian hukum normatif dan pendekatan peraturan perundang-undangan. Adapun data yang digunakan yaitu data hukum primer dan sekunder yang dikumpulkan melalui teknik dokumentasi dengan cara mengolah dan menganalisis literatur hukum yang telah terkumpul menggunakan argumentasi hukum. Hasil dari penelitian menunjukkan bahwa pengaturan putusan sela diatur dalam Pasal 185 HIR/196 RBg. Putusan sela dapat dibedakan ke dalam 4 golongan, yaitu preparatoir, interlocutoir, insidentil, dan provisi. Pertimbangan hakim dalam perkara perdata Nomor: 414/Pdt.G/2019/PN Dps Pemohon Intervensi memohon kepada Majelis Hakim untuk menggabungkan diri sebagai Penggugat Intervensi dengan dasar hukum sengketa kepemilikan tanah beserta bangunan di atasnya dengan kedudukan Pemohon Intervensi sebagai pembeli yang beritikad baik.
\end{abstract}

Kata Kunci: Gugatan, Hukum Acara Perdata, Putusan Sela

\begin{abstract}
The decision of the Panel of Judges on Civil Case No. 414/Pdt.G/2019/PN Dps, which continued the trial and set an interim decision even though one of the plaintiffs had died, contradicted the Jurisprudence of the Supreme Court of the Republic of Indonesia Number 431K/Sip/1973, dated May 9, 1974. This study aimed to examine the setting of interlocutory decisions on the civil procedural law and examine the judge's considerations in determining the continuation of the trial process in the case of decision Number: 414/Pdt.G/2019/PN Dps when the original plaintiff died. This research was designed by using normative legal research and legislation approaches. The data used were primary and secondary legal data collected through documentation techniques by processing and analyzing legal literature that had been collected using legal arguments. The results of the study indicated that the provision of interlocutory decisions was regulated in Article $185 \mathrm{HIR} / 196 \mathrm{RBg}$. Interlocutory decisions could be divided into 4 groups, namely preparatory, interlocutor, incidental, and provisional. The judges' considerations in civil cases Number: 414/Pdt.G/2019/PN Dps The Intervenient asked the Panel of Judges to be given the position of a Plaintiff-Intervenor based on the legal basis of disputes over property rights, over the land and buildings on it with the Intervenient's position as a buyer in good faith.
\end{abstract}

Keywords: Lawsuits, Civil Procedure Law, Interim Judgment

\section{PENDAHULUAN}

Negara Hukum seperti Negara Indonesia memiliki beragam aspekperaturan hukum yang memiliki sifat memaksa dan tentunya memiliki sanksi yang tegas apabila peraturan tersebut dilanggar (Satjipto, 2000). Selain itu, negara hukum juga memiliki arti sebagai sebuah sistem negara yang diatur sesuai dengan hukum yang saat ini sedang berlaku, yang adil dan tersusun dalam suatu konstitusi, dimana setiap orang yang ada di dalamnya, baik yang memerintah maupun yang diperintah, harus patuh pada hukum yang sama (Junadai, 2016). Definisi dasar dari hukum yakni aturan yang memiliki sifat memaksa untuk menentukan perilaku seseorang di kehidupan masyarakat yang dibuat oleh badan resmi yang berwenang, dimana pelanggaran yang dilakukan terhadap peraturan tersebut memberikan keputusan, dengan ketentuan yang berlaku (Sianturi, 2002). 
Segala perbuatan dan tingkah laku individu atau seseorang atau organisasi yang menyangkut individu atau organisasi lainnya maupun kepentingan sosial dimasyarakat akan terjamin hak-hak dan kewajibannya. Dalam kehidupan sehari-hari, terutama di masyarakat dalam menjalankan hak dan kewajiban sebagai seorang warga negara, tidak jarang seseorang atau sebuah organisasi memiliki pertentangan atau permasalahan hukum yang membuat salah satu pihak merasa haknya dirugikan, dihilangkan atau dicederai, namun halnya seseorang atau organisasi yang merasa hak-haknya telah dirugikan oleh pihak lain, pihak yang merasa dirugikan tersebut tidak diperkenankan untuk main hakim sendiri (eigenrichting), namun harus melalui prosedur yang benar sesuai ketentuan hukum yang berlaku saat itu (Achille, 2000).

Prosedur yang dapat digunakan dalam penyelesaian permasalahan tersebut yakni dengan cara mengajukan gugatan atau tuntutan hak kepada instansi Pengadilan Indonesia. Permintaan ganti rugi atas sebuah hak dapat dilihat dalam dua prespektif. Hukum pidana mengatur tentang perbuatan yang berkaitan dengan pelanggaran-pelanggaran, kejahatan- kejahatan yang berdampak pada kepentingan umum, yang disertai hukuman pidana bagi yang melakukan, dimana tata cara pelaksanaanya diatur oleh hukum acara pidana dan hukum perdata mengatur hukum yang berkaitan dengan kebenaran, keadilan, dan kepastian hukum dalam hal terjadi pelanggaran atau penyitaan atas aturan/ketentuan hukum materiil tentang tata cara atau tata kerja dalam hubungan yang benar yang melayani ketentuan hukum materiil, dimana tata cara pelaksanaanya diatur oleh Hukum acara perdata melaui prespektif hukum acara perdata, sebelum seseorang atau organisasi yang merasa haknya dirugikan tersebut melakukan gugatan atau tuntutan hak ke pegadilan, haruslah terlebih dahulu mempunyai syarat yang mutlak sehingga dapat mengajukan gugatan ke pengadilan, yaitu menjadi landasan adanya sengketa atau perselisihan.

Pengadilan merupakan suatu badan atau lembaga resmi yang menjadi pendukung dalam manuntaskan permasalahan yang dialami di dalam kehidupan bermasyarakat, sehingga tidak terjadi konflik yang membahayakan (Satyastuti et al., 2016). Di dalam pengadilan, terdapat seorang pengadil (Hakim) yang bertindak sebagai pemimpin dalam berjalannya suatu persidangan. hakim memiliki kekuasaan atas berjalannya suatu persidangan di dalam pengadilan demi tegaknya hukum serta keadilan berdasarkan Pancasila dan UUD Republik Indonesia Tahun 1945, sehingga putusannya memberikan keadilan kepada rakyat Indonesia khususnya kepada para pihak yang berperkara.

Implementasi peradilan perdata yang ideal, Hakim harus bertindak selaku penegak keadilan dan menegakkan kepatutan. Pertimbangan hukum sangatlah penting dalam memutuskan suatu perkara. Dalam hal ini, para hakim harus berani mementingkan faktor kepatutan, kelayakan, serta peraturan hukum yang logis dalam mengadakan keputusan. Keputusan tersebut dapat memuaskan atau sedikit-dikitnya mendekati kepada memuaskan para pihak yang bersengketa.

Melihat dan mempelajari keputusan Majelis Hakim terhadap Perkara Perdata No. 414/Pdt.G/2019/PN Dps, yang tetap melanjutkan persidangan dan menetapkan putusan sela walaupun salah satu pihak penggugat telah meninggal dunia, memberikan sebuah isu permasalahan yang mana menurut Yurisprudensi Mahkamah Agung R.I. Nomor 431K/Sip/1973, tanggal 9 Mei 1974, dengan patokan hukum yakni penggugat awal meninggal serta tidak terdapat persetujuan yang diberikan dari ahli warisnya untuk melanjutkan gugatan awal, maka gugatan harus dinyatakan gugur, ketentuan ini bertentangan dengan keputusan Majelis Hakim yang digunakan sebagai dasar untuk melanjutkan Perkara Perdata No. 414/Pdt.G/2019/PN Dps.

Berdasarkan fenomena tersebut, penelitian ini dilakukan dengan tujuan Untuk mengetahui pengaturan putusan sela dalam hukum acara perdata dan pertimbangan hakim dalam menentukan dilanjutkannya proses persidangan dalam perkara putusan Nomor: 414/Pdt.G/2019/PN Dps saat penggugat asal meninggal dunia.

\section{METODE PENELITIAN}

Karena penelitian ini berkaitan dengan kajian hukum yang bersifat sosial maka pengolahannya didesain dengan penelitian hukum normatif dengan menerapkan pendekatan perundang-undangan, dan yang berhubungan dengan konsep tersebut (konseptual). Sehingga dalam penyusunan penelitian ini, digunakan ada dua sumber bahan hukum, yakni bahan hukum primer yang terdiri dari Undangundang Dasar Negara Republik Indonesia Tahun 1945, Het Herzine Indonesisch Reglement (HIR), Reglemant Buaitengewesten (RBg.), Undang-undang No. 48 Tahun 2009 tentang Kekuasaan 
Kehakiman, Yurisprudensi. bahan hukum sekunder, yaitu bahan hukum yang memberi sebuah penjelasan tentang bahan hukum primer, contohnya penjelasan sesuai dengan yang terdapat dalam buku-buku ilmu hukum. Teknik yang digunakan dalam pengumpulan data yaitu teknik dokumentasi yang mana dilakukan dengan cara menginventarisasi bahan hukum seperti peraturan perundangundangan, literatur berupa buku-buku maupun bahan hukum lainnya yang memiliki hubungan dengan pengaturan hukum acara perdata (Soejono \& .Abdurrahman, 2003). Analisis bahan hukum yaitu jika semua bahan-bahan hukum yang diperlukan sudah terkumpul, lalu bahan hukum tersebut dikumpulkan dan dianalisis dan akan dikaji dan diberikan argumentasi untuk mendapatkan kesimpulan akhir penelitian ini (Soemitro, 1990).

\section{HASIL DAN PEMBAHASAN}

\section{Pengaturan Hukum Gugurnya Gugatan dalam Hukum Acara Perdata}

Perkara perdata pada dasarnya terjadi dikarenakan oleh salah satu pihak merasa tidak puas atau merasa telah dilanggar hak-hak keperdataannya atau kewajiban yang tidak dilaksanakan oleh pihak lainnya. Perkara perdata merupakan suatu perkara mengenai permasalahan sehubungan dengan hak dan kewajiban dalam ruang lingkup perdata, seperti permasalahan tentang perjanjian pengikatan jual beli, pinjam pakai, pembagian waris, dan lain-lain.

Seseorang, badan hukum atau kumpulan orang-orang yang merasakan oleh karena hak perdata mereka telah dirugikan oleh pihak yang lain, maka dapat mengajukan gugatan kepada pihak yang merugikan mereka. Namun diantara pihak- pihak, harus terjadi perselisihan dalah hal hukum. Pihak yang merugikan tersebut juga merupakan orang perseorangan, badan hukum, maupun kumpulan dari beberapa orang. Gugatan adalah sebuah tuntutan hak yang diajukan yang memiliki suatu kepentingan hukum, yang dapat dikabulkan gugatannya oleh hakim apabila kebenarannya dalam gugatan tersebut dapat dibuktikan pada saat persidangan pemeriksaan (Chandranegara \& Fakultas, 2017). Gugatan tersebut haruslah diajukan oleh orang yang berkepentingan atau kuasanya. Dasar hukum dalam sebuah gugatan pada umumnya adalah wanprestasi dan perbuatan melawan hukum.

Putusan merupakan sebuah pernyataan yang dibuat langsung oleh hakim, yaitu sebagai penyelenggara negara yang memiliki kewenangan untuk melakukan hal tersebut, disampaikan langsung saat di dalam persidangan yang mana memiliki tujuan untuk mengakhiri dan menyelesaikan suatu perkara diantara para pihak yang berperkara (Pitoyo, 2012). Setelah seluruh proses pemeriksaan terselesaikan dan sudah tidak ada lagi yang ingin disampaikan dalam persidangan oleh para pihak, maka hakim akan memberikan keputusan terhadap hasil dari perkara tersebut. Putusan yang disampaikan oleh hakim di dalam persidangan harus sama dengan yang ditulis. Sebuah keputusan yang sah adalah keputusan yang diucapkan oleh hakim di dalampersidangan secara resmi. Secara garis besar, dalam acara perdata, putusan hakim dapat dibedakan menjadi dua berdasarkan waktu penjatuhannya, yaitu putusan akhir (eind vonnis) dan putusan sela (tussen vonnis).

Putusan sela merupakan suatu putusan terhadap suatu perkara yang dijatuhkan oleh hakim sebelum putusan akhir yang berfungsi mempermudah atau memperlancar dalam kelanjutan pemeriksaan perkara tersebut. Dalam sebuah Putusan sela berisikan perintah-perintah yang harus diikuti oleh para pihak yang teribat dalam perkara tersebut. Putusan ini juga berfungsi untuk memberikan kemudahan kepada hakim dalam menyelesaikan pemeriksaan terhadap perkara tersebut yang dilakukan sebelum menjatuhkan putusan akhir (Harahap, 2017). Putusan sela dibagi menjadi 4 golongan, yaitu putusan preparatoir, putusan interlocutoir, putusan insidentil, dan putusan provisi (provisional). Tidak semua perkara perdata dapat diajukan sebuah putusan sela, namun dalam perkara keperdataan yang dapat diajukan putusan sela adalah terhadap sebuah perkara perdata yang perlu melakukan pemeriksaan di tempat, putusan pemisahan dari beberapa gugatan yang telah diajukan, putusan provisi dan putusan yang bertujuan untuk memerintahkan adanya pembuktian yang dilakukan dengan pemeriksaan dari saksi-saksi di dalam persidangan.

Penjatuhan putusan sela ini penting karena merupakan bagian dari proses peradilan perkara perdata, kepentingan penegakan hukum dan keadilan di masyarakat. Penegakan hukum bertujuan untuk pihak-pihak yang mencari keadilan tidak dikecewakan oleh lembaga peradilan itu sendiri. Sekalipun putusan sela harus diucapkan dalam sidang, tidak dibuat dengan putusan sendiri, melainkan tertulis dalam berita acara sidang. Hakim boleh memberikan salinan dari berita acara tersebut, jika 
para pihak menginginkan putusan yang bukan putusan akhir tersebut. Dalam prosesnya, putusan sela dapat diajukan banding hanya jika bersama-sama dengan putusan akhir.

\section{Pertimbangan Hakim dalam Menentukan Dilanjutkannya Proses Persidangan Perkara Putusan Nomor: 414/Pdt.G/2019/PN Dps Saat Penggugat Asal Meninggal Dunia}

Surat gugatan adalah sebuah surat yang diajukan oleh penggugat kepada Ketua Pengadilan yang berwenang, dimana di dalamnya berisikan tuntutan dari hak-hak yang di dalamnya berisikan sebuah sengketa dan juga menjadi dasar dari pemeriksaan dan serta pembuktian dari kebenaran mengenai suatu hak dalam rengketa perkara tersebut (Svinarky Irene, 2019:2). Bentuk gugatan yang dibenarkan menurut undang-undang adalah gugatan dalam bentuk lisan dan bentuk tertulis. Gugatan dalam bentuk tertulis merupakan gugatan yang paling umum ditemui dan paling diutamakan. Hal ini ditegaskan pada Pasal 188 Ayat 1 HIR dan dijelaskan pula pada Pasal 142 ayat $1 \mathrm{RBg}$. Menurut kedua pasal tersebut di atas, jelas menyebutkan bahwa surat gugatan diajukan dalam bentuk surat permohonan yang ditandatangani oleh penggugat atau kuasanya dan disampaikan kepada Ketua Pengadilan Negeri yang menguasai wilayah hukum tempat tinggal tergugat, atau tempat tinggal yang sebenarnya. Penggugat dalam perkara perdata terlebih dahulu harus mendaftarkan surat gugatan ke Kepaniteraan Pengadilan Negeri yang berwenang. Dalam sebuah gugatan yang diajukan oleh penggugat, akan ada pihak-pihak yang merasa bahwa hak-hak yang mereka miliki tersebut dilanggar, namun pihak yang dirasa melanggar hak tersebut tidak akan secara sukarela akan melakukan hal tersebut (Sugeng \& Sujayadi, 2012).

Jika slah satu pihak tidak dapat menghdiri persidangan sesuai dengan yang telah ditentukan maka akan berlaku acara istimewa seperti yang telah diatur pada Pasal 124 HIR yang mengatur perihal gugur atau sebelum pemanggilan, pihak penggugat telah meninggal dunia, maka perkara tersebut diserahkan kepada pihak ahli warisnya untuk melanjutkan atau mencabut untuk tidak melanjutkan perkara yang bersangkutan. Para ahli waris hendaknya datang untuk menghadap Ketua Pengadilan Negeri terkait untuk menyampaikan maksud dan tujuannyanya tersebut. Jika para ahli hendak untuk melanjutkan gugatan yang telah diajukan tersebut, maka surat gugatan tersebut haruslah diubah dengan memasukkan para ahli waris sebagai penggugat.

Pertimbangan hakim adalah suatu aspek yang pentying dalam menentukan keputusan yang akan dibuat oleh hakim yang memiliki keadilan, kepastian dalam hukum, dan juga mengandung kegunaan bagi para pihak yang bersangkutan oleh karena itu pertimbangan yang diberikan oleh hakim haruslah teliti, baik, serta cermat. Hakim dalam hal memutuskan perkara haruslah bebas serta tidak dipengaruhi oleh pihak mana pun. Hakim yang bersifat netral serta tidak memihakdengan pihak manapun, agar terciptanya keadilan di dalam putusan-putusan yang dibuat oleh hakim tersebut. Jaminan dari kebebasan tersebut diatur dalam Pasal 24 Undang-Undang Dasar Negara Republik Indonesia Tahun 1945 dan ditegaskan juga dalam Pasal 1 Ayat 1 Undang-undang Nomor 48 Tahun 2009 tentang Kekuasaan Kehakiman peraturan-peraturan tersebut merupakan dasar Majelis Hakim dalam membuat suaru putusan. Pertimbangan Majelis Hakim dalam menjatuhkan putusan sela diantaranya disebabkan oleh adanya pihak yang merasa berkepentingan dalam sebuah perkara perdata yang sedang berjalan. Seperti halnya dalam perkara putusan Nomor: 414/Pdt.G/2019/PN Dps, dimana Pemohon Intervensi memohon kepada Majelis Hakim untuk menggabungkan diri sebagai penggugat intervensi dengan dasar hukum sengketa hak kepemilikan tanah beserta bangunan di atasnya dengan kedudukan pemohon intervensi sebagai pembeli yang beritikad baik. Alasan inilah yang dapat menjadi dasar Majelis Hakim memberikan suatu pertimbangan untuk menjatuhkan putusan sela.

Menjatuhkan suatu putusan sela bukan merupakan hal yang mudah untuk diterima, sebab putusan sela yang jatuh tidak hanya untuk keperluan pemohon saja, beberapa tanggapan dari pihak yang berperkara juga tetap harus menjadikannya sebagai alasan diterima atau tidak permohonan dari penjatuhan putusan sela itu. Jatuhnya putusan sela tersebut bukanlah hanya merupakan kepentingan dari pihak-pihak yang memohonkan saja, tetapi juga untuk menjaga kelancaran serta tegaknya pelaksanaan dari hukum tersebut. Sebagaimana diatur dalam azas peradilan perkara peradata bahwa Hakim dalam peradilan harus bersifat netral dan tidak berpihak, sedangkan yang berhak membuktikan kebenaran gugatan adalah pihak yang berperkara. 
Pokok perkara dalam Register Nomor: 414/Pdt.G/2019/PN Dps ini mengadili perbuatan melawan hukum yang dilakukan oleh Tergugat. Penggugat asal pada awalnya datang menghadap diwakili oleh kuasanya dengan surat kuasa khusus. Namun, ketika proses persidangan sedang berjalan, penggugat asal meninggal dunia. Penggugat asal meninggal dunia pada tanggal 8 Agustus 2019 sebagaimana dibuktikan dengan surat keterangan dan surat bukti pelaporan kematian WNI di luar negeri. Dengan Penggugat asal telah meninggal dunia, para ahli waris dari Penggugat asal yang bukan pada hari yang sama, melainkan pada hari berikutnya, nantinya menyatakan akan menggantikan dan melanjutkan perkara ini melalui kuasa hukumnya, yang dibuktikan pada surat kuasa khusus tertanggal 16 Oktober 2019. Pada hari serta tanggal yang sama, yakni pada tanggal 8 Agustus 2019, agenda sidang adalah membahas keikutsertaan pemohon intervensi sebagai pihak penggugat intervensi dalam perkara perdata Nomor: 414/Pdt.G/2019/PN Dps, dengan alasan sengketa hak kepemilikan tanah beserta bangunan di atasnya dengan kedudukan Pemohon Intervensi sebagai pembeli yang beritikad baik. Dalam persidangan tanggal 8 Agustus 2019, terjadi dua pertistiwa hukum, yakni pemberitahuan atas meninggalnya Penggugat asal kepada Majelis Hakim dan penentuan putusan sela tentang status bergabungnya Pemohon Intervensi sebagai Penggugat Intervensi. Terhadap pemberitahuan peristiwa hukum meninggal dunianya Penggugat asal, Majelis Hakim telah melanjutkan persidangan ketika pengugat asal belum meiliki kuasa hukum dan ahli waris yang akan meggantikan dan melanjutkan perkara. tentang ahli waris, yang mana memang telah menyatakan akan menggantikan dan melanjutkan perkara dengan kuasa hukumnya berdasarkan Surat Kuasa Khusus pada tanggal 16 Oktober 2019.

Berdasarkan analisis yang didapat dari tanggal yang terdapat dalam putusan, Majelis Hakim memberikan keputusan pada hari yang sama dimana penggugat asal meninggal dunia dan belum terwakilinya pihak Penggugat Asal oleh ahli warisnya. Menurut pasal 1813 Kitab Undang-undang Hukum Perdata. Pasal tersebut menjelaskan bahwa, salah satu sebab surat kuasa gugur atau berakhir adalah ketika pemberi kuasa meninggal dunia. Dengan demikian, surat kuasa yang diberikan oleh Penggugat asal kepada kuasa hukumnya telah gugur

\section{SIMPULAN DAN SARAN}

\section{Simpulan}

Berdasarkan analisis data diketahui bahwa Pengaturan dari putusan sela yang diatur dalam Pasal 185 HIR/196 RBg. semua putusan sela harus diucapkan di dalam persidangan, dicatat dalam berita acara dan para pihak dapat memperoleh salinan otentik dari berita acara yang berisikan putusan sela. Berdasarkan teori dan praktiknya, putusan sela dapat dibedakan ke dalam 4 golongan, yaitu putusan preparatoir, putusan interlocutoir, putusan insidentil, dan putusan provisi. Fungsi putusan sela dalam suatu perkara perdata Nomor: 414/Pdt.G/2019/PN Dps ini adalah mengabulkan permohonan pihak Pemohon Intervensi yang merasa mempunyai kepentingan dalam perkara perdata tersebut untuk menjadi Penggugat Intervensi. Pertimbangan yang diberikan oleh hakim adalah aspek yang penting dalam menentukan sebuah putusan yang dibuat oleh hakim yang berisi keadilan, kepastian hukum yang bermanfaat bagi pihak yang berkaitan sehingga dalam memberikan pertimbangannya, hakim haruslah teliti, tegas, baik, dan cermat. Dalam perkara perdata Nomor: 414/Pdt.G/2019/PN Dps Pemohon Intervensi memohon kepada Majelis Hakim untuk menggabungkan diri sebagai Penggugat Intervensi dengan dasar hukum sengketa hak kepemilikan tanah beserta bangunan di atasnya dengan kedudukan Pemohon Intervensi sebagai pembeli yang beritikad baik. Alasan tersebut dapat menjadi salah satu pertimbangan Majelis Hakim dalam menjatuhkan putusan sela dalam perkara perdata tersebut.

\section{Saran}

Dari simpulan penelitian di atas, adapun saran yang diberikan peneliti adalah bagi pemerintah, seharusnya Majelis Hakim dapat lebih mempertimbangkan terlebih dahulu sebelum menjatuhkan suatu putusan. Seharusnya pemerintah khususnya badan hukum legislatif dapat lebih mempertimbangkan perarturan tersebut agar ditetapkan menjadi sebuah aturan hukum, mengingat kasus tersebut tidak hanya sekali terjadi di dalam peradilan, dan guna menghindari pihak yang mengalami kasus serupa merasa haknya dirugikan. Bagi masyarakat, untuk menghindari penjelasan bahwa putusan sela hanya digunakan untuk kepentingan salah satu pihak, dan diharapkan 
masyarakat umum sebagai subjek hukum dapat lebih meningkatkan pemahaman hukum khususnya yang terkait dengan putusan sela dan hukum acara perdata yang berlaku.

\section{DAFTAR PUSTAKA}

Achille, N. (2000). Etika Hukum Beserta Sanksi Elektronik. Jakarta. Sinar Grafika.

Chandranegara, I. S., \& Fakultas. (2017). Desain Konstitusional Hukum Migas untuk SebesarBesarnya Kemakmuran Rakyat. Jurnal Konstitusi, 14(1), 45-80.

Harahap, M. Y. (2017). Hukum Acara Perdata tentang Gugatan, Persidangan, Penyitaan, Pembuktian, dan Putusan Pengadilan. Sinar Grafik.

Junadai, M. (2016). Ilmu Negara Sebuah Konstitusi Ideal Negara Hukum. Sinar Grafika: Malang.

Pitoyo, W. (2012). Strategi Jitu Memenangi Perkara Perdata dalam Praktik Peradilan. Transmedia Pustaka: Jakarta.

Satjipto, R. (2000). Ilmu Hukum. Citra Aditya Bakti.

Satyastuti, N. W. R., Sari, C. A. T., \& Vaundra, V. A. (2016). Proses Penyelesaian Tindak Pidana Desersi yang Dilakukan oleh Anggota Tentara Nasional Indonesia. Jurnal Verstek, 4(2), 10-17.

Sianturi, S. R. (2002). Asas-Asas Hukum Pidana di Indonesia dan Penerapan. Storia Grafika.

Soejono, \& .Abdurrahman, H. (2003). Metode Penelitian Hukum. Jakarta. Rineka Cipta.

Soemitro, R. H. (1990). Metodologi Penelitian Hukum dan Jurumetri. Jakarta. Ghalia Indonesia.

Sugeng, B., \& Sujayadi. (2012). Pengantar Hukum Acara Perdata dan Contoh Dokumen Litigasi. Kencana: Jakarta. 